\title{
Interconfessional analysis of use and related problems: the Christians and Muslims
}

\author{
Menizibeya Welcome Osain*, Vladimir Pereverzev Alekseevic \\ From $1^{\text {st }}$ International Congress on Neurobiology and Clinical Psychopharmacology and European \\ Psychiatric Association Conference on Treatment Guidance \\ Thessaloniki, Greece. 19-22 November 2009
}

\section{Background}

The confession to which a person has been committed to will likely influence his/her attitude towards alcohol use. Many studies have suggested that the problem of alcohol use between people of different confession, although might differ, the gap is narrowing $[1,2]$. We therefore examine the differences in the pattern of alcohol use among people of different confessions - the Christians and Muslims in Minsk, Belarus.

\section{Materials and methods}

The study was randomized and anonymous. Altogether, 214 (107 Christians and 107 Muslims) people were explained the study aims and objectives. A total 65 Christians and 70 Muslims agreed to participate in the study. All respondents were administered the AUDIT, CAGE and MAST questionnaire. Statistical analysis was performed using SPSS 16.0 version for Windows and the Pearson $\chi 2$.

\section{Results}

The present study revealed that no differences in both the number of alcohol users and problem drinkers exist (according to the results of all three screening instruments) among the Christians and Muslims. Alcohol users were $67.69 \%(\mathrm{n}=44)$ Christians and $57.14 \%$ $(\mathrm{n}=40)$ Muslims. Problem drinkers were $27.69(\mathrm{n}=18)$ Christians and Muslims - 34.29\% (24).

\section{Conclusions}

This study is an exceptional case, where for both Christians and Muslims, the percentages (as well as the average scores in the various screening instruments) of alcohol users and problem drinkers were the same on

Department of Human Physiology, Belarusian State Medical University, Minsk, Belarus the AUDIT, CAGE and MAST. According to the result of this study, no difference in the pattern of alcohol use exist among people of different confession in Minsk, Belarus

Published: 22 April 2010

\section{References}

1. Heath DB, ed: International Handbook on Alcohol and Culture. Westport, CT: Greenwood Press 1995

2. Bloomfield K, et al: Gender, Culture and Alcohol Problems: A Multinational Study. Project Final Report Berlin: Institute for Medical Informatics, Biometrics \& Epidemiology, Charité Universitätsmedizin Berlin 2005.

doi:10.1186/1744-859X-9-S1-S222

Cite this article as: Osain and Alekseevic: Interconfessional analysis of use and related problems: the Christians and Muslims. Annals of General Psychiatry 2010 9(Suppl 1):S222.
Submit your next manuscript to BioMed Central and take full advantage of:

- Convenient online submission

- Thorough peer review

- No space constraints or color figure charges

- Immediate publication on acceptance

- Inclusion in PubMed, CAS, Scopus and Google Scholar

- Research which is freely available for redistribution

Submit your manuscript at www.biomedcentral.com/submit
Biomed Central 